\title{
Unexpected Displacements of Chloride by Bromide Found During Sandmeyer Reactions of 3- or 5-Amino-2-chloropyridines
}

\author{
A. Paul Krapcho* and Simon N. Haydar \\ Department of Chemistry, The University of Vermont, Burlington, Vt 05405 USA
}

\begin{abstract}
Facile, temperature dependent displacements of chloride by bromide have been found in the diazotizations of 3-amino-2-chloropyridine (1a) or 5-amino-2-chloropyridine (1b), followed by addition of $\mathrm{CuBr}$ in $48 \% \mathrm{HBr}$, which lead to good yields of the unexpected 2,3-dibromopyridine (3a) or 2,5-dibromopyridine (3b), respectively.
\end{abstract}

We wish to report an unusually facile, temperature dependent displacement of chloride by bromide observed during a Sandmeyer reaction of 3-amino-2-chloropyridine (1a) in the preparation of 2-chloro-3bromopyridine (2a). The diazotization of $1 \mathrm{a}$ in $48 \%$ aqueous $\mathrm{HBr}$ at $-15^{\circ}$ to $-10^{\circ} \mathrm{C}$, followed by the addition of 0.9 molar equivalents of $0.7 \mathrm{M} \mathrm{CuBr}$ in $48 \%$ aqueous $\mathrm{HBr}$ at $-20^{\circ}$ to $-10^{\circ} \mathrm{C}$, has been reported to yield $2 \mathrm{a}(97 \%)$ (1). However, if the diazotization was performed at a higher temperature $\left(25^{\circ} \mathrm{C}\right)(2)$, followed by the addition of $\mathrm{CuBr}$ in $48 \% \mathrm{HBr}$ (temperature rose to $32^{\circ} \mathrm{C}$ ), the major product obtained was 2,3-dibromopyridine (3a) (3) along with 2-chloro-3-bromopyridine ( $2 \mathrm{a}_{-}$) in a 2.3:1 ratio, respectively. If the temperature of the mixture was kept at $-30^{\circ} \mathrm{C}$ to $-20^{\circ} \mathrm{C},-15^{\circ} \mathrm{C}$ to $-10^{\circ} \mathrm{C}$ or $0-5^{\circ} \mathrm{C}$ during the course of the diazotization and the addition of $\mathrm{CuBr}$, the $2 \mathrm{a}: 3 \mathrm{a}$ product ratios were 100:0 (no detectable $3 \mathrm{a}$ by ' $\mathrm{H} \mathrm{nmr}$ ), 4:1 and 1:1, respectively. A control experiment in which 1a was treated with $48 \% \mathrm{HBr}$ and allowed to stir for 4 hours at room temperature led only to recovered starting material.<smiles>[X]c1cnc(Cl)c([X])c1</smiles><smiles>[X]c1cnc(Cl)c([X])c1</smiles>

$$
\begin{aligned}
\text { 1a, } X=\mathrm{NH}_{2}, Y=\mathrm{H} \\
\text { b, } X=\mathrm{H}, Y=\mathrm{NH}_{2}
\end{aligned}
$$

$2 \mathrm{a}, \mathrm{X}=\mathrm{Br}, \mathrm{Y}=\mathrm{H}$

b $, X=H, Y=B r$<smiles>[X]c1cnc(Br)c([X])c1</smiles>

3a $, \mathrm{X}=\mathrm{Br}, \mathrm{Y}=\mathrm{H}$

b , $X=H, Y=B r$

Following a similar procedure as described for $1 \mathbf{a}$, it was found that 2-chloro-5-aminopyridine (1b) at temperatures of $-30^{\circ} \mathrm{C}$ to $-20^{\circ} \mathrm{C}$ led only to $\underline{2 \mathrm{~b}}$. However, if the reaction was performed at $25^{\circ} \mathrm{C}, \underline{\mathbf{2 b}}$ and $\underline{3 \mathrm{~b}}$ (4) were obtained in equal amounts.

On the other hand, the diazotization and addition of $\mathrm{CuBr}$ to the carbocyclic models, 2-chloroaniline and 2-chloro-4-aminopyridine (5), at room temperature led only to the expected bromo analogues 2-bromo-2chlorobenzene and 2-chloro-4-bromopyridine (6), respectively. These results point to the importance of the nitrogen atom in the ring and the position of the amino group in obtaining dibromo products $\underline{3 a}$ and $\underline{3 b}$ from 1 a 
and 1b, respectively.

It might be noted that displacements of the chlorides from 2,6-dichloropyridine with acetic acid saturated with hydrogen bromide gas required heating at $110^{\circ} \mathrm{C}$ for 9 hours to prepare the corresponding dibromo analogues (7). Clearly the diazonium ion must be responsible for the high displacement rates of chloride by bromide found at higher temperatures in the cases of $\underline{1 \mathrm{a}}$ and $\underline{1} \mathrm{~b}$. The rate of displacement of fluoride by methoxide in 4fluorobenzene diazonium tetrafluoroborate and 4-fluoronitrobenzene has been reported to be 300,000 times faster for the $\mathrm{N}_{2}{ }^{+}$group relative to the nitro group (8). In the preparation of fluoroanisoles, the diazonium ion was proposed as an efficient activator for $S_{N} A r$ substitutions (9).

Diazotization of 1 a would lead to $\mathbb{4}_{\mathrm{a}}$ which at room temperature, and before loss of nitrogen could undergo nucleophilic addition of bromide to form intermediate_5. (only one resonance stucture is shown). Loss of chloride from 5 , followed by replacement of the diazonium group by bromide, would lead to 3a. Similarly, an $S_{N} A r$ route of this type would lead to $3 \mathrm{~b}$ on diazotization of $1 \mathrm{~b}$. On the other hand, 4-amino-2-chloropyridine on diazotization has the diazonium ion in an unfavorable position for activation via an $S_{\mathbb{N}} A r$ substitution pathway and led only to the expected product 4-bromo-2-chloropyridine.

Scheme 1. Possible mechanism for $S_{N}$ Ar displacement of chloride by bromide.

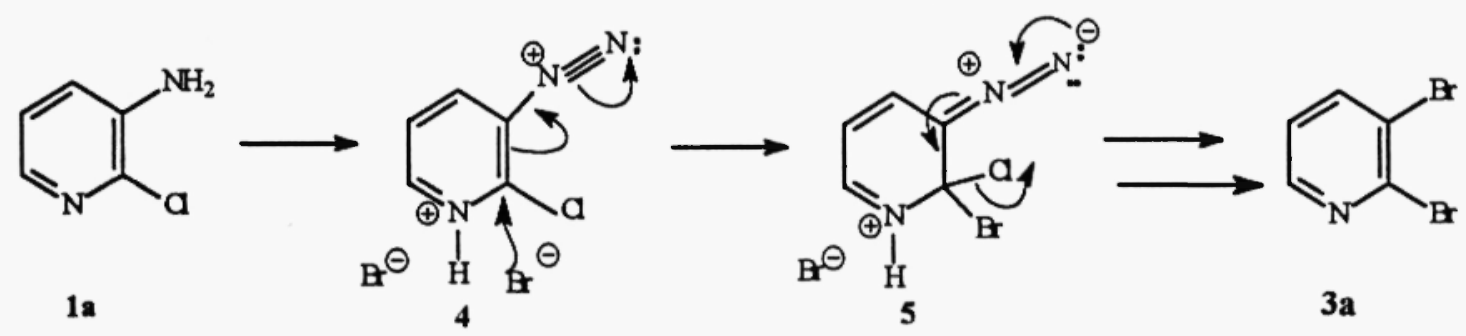

\section{References and Notes}

1. J. D. Cook and B. J. Wakefield, J. Chem. Soc. (C) 1973 (1969).

2. All temperatures which we report are internal. Product ratios were determined by ${ }^{4} \mathrm{H} \mathrm{nmr}$ integrations. All yields were greater than $90 \%$, except in the case of 4-amino-2-chloropyridine which was converted to product in about $50 \%$ yield.

3. Compound 3a was prepared following the procedures described in: a) R. A. Abramovitch, F. Helmer and M. Levis, J. Org. Chem . 34, 1730 (1969) and b) M. P. Cava and B. Weinstein, J. Org. Chem. 23, 1616 (1958). Product ratios were determined by integrations of the protons adjacent to the nitrogen atoms $[\delta$ for $2 \mathrm{a}(8.37)$ and $3 \mathrm{a}(8.34) \mathrm{ppm}]$.

4. Compounds $1 \mathrm{~b}$ and $3 \mathrm{~b}$ were purchased from Aldrich. The ratios of products were determined by ${ }^{\prime} \mathrm{H} \mathrm{nmr}$ integrations of the protons meta to the nitrogen atom [ $\delta$ for $2 \mathrm{~b}(7.79)$ and $3 \mathrm{~b}(7.68) \mathrm{ppm}]$.

5. This compound was prepared following the procedures described in: a) M. Malinowski and L. Kaczmarek, J .Prakt. Chem. 330, 154 (1988) and b) E.V. Brown, J. Am. Chem. Soc. 79, 3565 (1957).

6. M.. Mallet and G. Queguiner, Tetrahedron 42, 2253 (1986). A ${ }^{1} \mathrm{H} \mathrm{nmr}$ is reported for this compound.

7. H. Mutterer and C. B. Weis, Helv. Chim. Acta 59, 229 (1976).

8. B. A. Bolto, M. Livens and J. Miller, J. Chem. Soc. 750 (1956).

9. N. Takechi, Y. Fukai, K. Oka and R. Huisgen, Chemistry Lett. 23 (1996).

\section{Received on March 3, 1998}

